\title{
Sustainable Growth of Indonesia Palm Oil Companies: Synchronizing Agility, Culture, and Engagement
}

\author{
Nopriadi Saputra, Ningky Sasanti, Reni Hindriari, \\ \{ nopriadi.saputra@binus.ac.id ${ }^{1}, \underline{\text { nky@ppm-manajemen.ac.id }}, \underline{\text { dosen00227@unpam.ac.id }}$ \}
}

\begin{abstract}
Bina Nusantara University, Jalan Raya Kebun Jeruk no 27 Jakarta Bara $11530^{1}$, Sekolah Tinggi Manajemen PPM, Jalan Menteng Raya no 9 Jakarta Pusat $10340^{2}$, Universitas Pamulang, Jalan Surya Kencana 1 Tanggerang Selatan $15417^{3}$
\end{abstract}

\begin{abstract}
The lack of work engagement from the millennials is becoming a strategic issue in managing managerial resources. This article is an attempt to examine work engagement of managerila resources in palm oil industry and to examine the impact of corporate culture and business agility on work engagement. This article was based on quantitative and cross-sectional research which involved 477 managers and supervisors. Collecting data was based on PLS structural equation model and using SmartPLS version 3.0 for computing and testing the research model. The result of statistical analysis explains that holistic work engagement is influenced directly by learning agility, leadership agility, and strategic agility. Learning culture influenced indirectly on holistic work engagement. For keeping sustainable growth this article recommends for palm oil companies to develop multi-layer agility in every layer of organization and aligning the corporate culture to support agility development.
\end{abstract}

Keywords: corporate culture, business agility, work engagement

\section{Introduction}

Because of its highest productivity and lowest production of cost, it makes crude palm oil (CPO) becomes main substitute commodity for soybean, rapeseed and sunflower oil as the source of vegetable oil [1]. For the national interest, palm oil production reached 37.8 million tonnes in 2017 and contributed to around $12 \%$ of the country's non oil and gas exports. In the context of global trade, Indonesia produced 58\% while Malaysia produced 29\% in the global market of CPO [2]. Indonesia is the world leader in CPO production and has been successful in serving the world and domestic market with palm products and palm derivatives [3].

As an important and strategic industry, the oil palm plantation companies are facing a various challenges both in ecological, social and managerial perspective for aiming sustainable growth. This article is focused on managerial 
issues, especially related to talent shortage in managerial resources. Based on data from Survey Tenaga Kerja Nasional 2018; Indonesian labor force working in the agriculture, forestry and fisheries sectors experienced a generationally decline. Baby Boomer and Veterans generation was around 43.57\% who worked in the agriculture, forestry and fishing sector. But the portion dropped dramatically to only $23.61 \%$ in the Gen-X generation and continues to decline to 16.04 in Millennials generation. [4]. This declining trend leads to the decreasing talent supply for managerial resources in oil palm plantation companies.

Relating to this talent shortage, oil palm plantation companies should be able to effectively answer the two important questions: (1) how to obtain and retain managerial resources to work over a long period and (2) how to obtain and retain managerial resource to work in a challenging remote locations. This article uses work engagement as an theoritcal concept. The work engagement of managerial resources directly impact on the productivity, retention, financial performance, and shareholder return [5].Meanwhile, related to how to work in a challenging remote locations, this paper uses the concept of business agility as an approach. More than $60 \%$ of the employers need to improve their employee's capability in adaptability, innovation, flexibility, resilience and critical thinking [6]. Organizational effectiveness in the twenty-first century is dependent on business agility with blending systems, leadership and culture, for supporting decision making and dynamic capability [7].

Therefore this paper is focused on work engagement, business agility, corporate culture, and its interrelationship. The previous studies just viewed work engagement in fragmented framework. This article proposes concepts of work engagement in holistic perspective. Work engagement is reflected into physical, intellectual, emotional, and spiritual engagement. For leveraging work engagement holistically of millenials as managerial resources in oil palm companies, does the business agility affect the holistic work engagement or not? This article conceptualizes business agility into multi-layer perspective which elaborates business agility in three different layer: (1) learning agility for individual layer, (2) leadership agility for group layer and (3) strategic agility for organization layer.

For developing multi-layer agility, does corporate culture impact directly or not? This article elaborates learning culture as variant of corporate culture. Learning culture facilitates individual and collaborative learning for all people in organization. Learning culture is perceived as the antecedent of business agility and impact indirectly on work engagement. Based on these reasons, this article aims to find out the synchronized relationship between culture, agility, 
and engagement for reaching sustainable growth in oil palm plantation companies.

\section{Literature Review}

This articles is developed by considering three main theoretical concepts such as holistic work engagement, multi-layer agility, and learning culture.

\subsection{Holistic Work Engagement}

As one of the most popular management tools [8], work engagement was first introduced by William A Kahn [9] and popularized among practitioners and scholars in management by book with tittle First! Break all the Rules [10]. According to JD-R or job demand and resources model [11]; work engagement is being stronger when work demand which is perceived by employee is lower and job resources is higher. Work engagement is defined as "a relatively enduring state of mind referring to the simultaneous investment of personal energies in the experience or performance of work" [12].

Generally, work engagement is reflected into three dimensions: availability meaningfulness, and safety [9]; efficacy, energy, and involvement [13] and absorption, dedication, and vigour [14]. For being adaptive in dealing with continuous and disruptive changes [15], this article consider to redefine work engagement into holistic framework of human resources development [16]. Based on holistic framework, human resources development is not limited only in emotional, intellectual and physicaland aspects; but also elaborate the spirituality as the fourth aspect. This article uses holistic work engagement as for measuring work engagement holistically into four dimensions: physical, intellectual, emotional, and spiritual engagement.

According to systematic literature review [17], the intervention for leveraging work engagement can be grouped into four categories: (1) personal resource building interventions; (2) job resource building interventions; (3) leadership training interventions; and (4) health promoting interventions. This article elaborates the impact of learning culture, learning agility, leadership agility, and strategic agility on work engagement. Learning culture is a part of job resource building intervention. Learning agility is a part of personal resource building intervention. Leadership agility and strategic agility are part of leadership training intervention. 


\subsection{Multi-Layer Agility}

Turbulence in the business environment imposed business organizations to become more agile in doing business [15]. Business agility is the organizational capability to innovate through collaboration and to anticipate business challenges and opportunities before disruptive changes occur [18]. Developing business agility should be applied in the whole organization, in every layer of organization [19]. Organizational behavior [20] views business organization into three layers: individual, group, and organization. This article conceptualizes business agility with three different constructs. Those are learning agility for individual layer, leadership agility for group layer, and strategic agility for organization layer.

Learning Agility is more than learning ability [21] is believed as the construct to predict current performance, future potential, and adaptability to a vibrant dynamic environment [22] Learning agility is defined as the individual capability to be flexible and fast in utilizing experience to overcome the newly and complicated situations [23] which is reflected into change agility, mental agility, people agility, and result agility [24].

Previous study in Indonesia's oil palm industry which involved 73 senior staffs, supervisors and junior managers from 28 companies revealed that learning agility impacts directly on work engagement [25]. Based on those studies, this article want to test the impact of learning agility statistically on holistic work engagement.

\section{H1: Learning Agility impact on Holistic Work Engagement significantly}

Leadership Agility is perceived individual ability of manager or supervisor to lead group of people flexibly and quickly [26] in sensing and responding to business changes [27] as well as the ability to unlearn and relearn about the relevant sources of success [28].Leadership agility is reflected into four dimensions: self-leadership agility, context-setting agility, stake-holder agility, and creativity agility [29].

Previous study which involved 697 employees working in Italian and Pakistani hospitality industry revealed that ethical leadership have positive impact on, work engagement [30]. Another study from a large salon chain in the United Kingdom which involved 187 teams and 903 leader-follower dyads also revealed that work engagement mediates the relationship between service 
leadership and followers' service performance. Service leadership impacts on work engagement significantly [31]. Based on those studies, this article suppose to examine the impact of leadership agility on holistic work engagement statistically.

\section{H2: Leadership Agility impacts on Holistic Work Engagement significantly}

A qualitative study in Indonesia which involved 170 owner and manager of Batik micro small medium enterprises in Pekalongan found that leadership agility impacts on organizational learning and organizational innovation [32]. Another study in USA which involved 116 executives of multi national companies revealed that overall leadership competences impacts on learning agility significantly [33]. Based on these empircal evidents, this article suppose to examine the impact of leadership agility on learning agility.

\section{H3: Leadership Agility impact on Learning Agility}

Strategic Agility is organizational capability to be flexible and fast [34] in monitoring business opportunities and capturing values [35] through optimizing and reconfiguring organizational strength to pursuit business sustainability [36]. Strategic agility is reflected into three dimension: strategic sensitivity, leadership unity and resource fluidity [37].

Empirical study in Egypt which involved 315 employees found organizational agility directly affects job engagement [38]. Related to that study, this article suppose to examine statistically the impact of strategic agility on holistic work engagement.

\section{H4: Strategic Agility impacts on Holistic Work Engagement significantly}

A study in Europe which involved 60 CEO of high-tech companies has proved that top management support impact on organizational learning, technological skill, and technological distinctive competence [39]. The study implisitly explained that top management support as strategic capability impact on technological skill and distinctive competence as individual learning capability. Based on the study, this article suppose to examine the impact of strategic agility on learning agility.

H5: Strategic Agility impacts on Learning Agility significantly 
Empirical study in Ardabil which involved 76 governmental organizations staffs found that strategic agility impacts on transactional leadership [40]. Related to the empirical study, this article need to test statistically impact of strategic agility impacts on leadership agility.

H6: Strategic Agility impacts on Leadership Agility significantly

\subsection{Learning Culture}

A learning culture is considered effective when it is supporting the organizational objectives and breeding ground for the learning needed within the organization [41]. Learning culture is a derivative concept of corporate or organizational culture. It comes from the culture concept in sociology which is directed to encourage and facilitate people in organization to conduct individual and collaborative learning.

Learning culture is defined as a culture that focuses on promoting and facilitating learning for the whole organization for aiming organizational performance [42]. By developing learning culture in business organization, it stimulates experimentation, fosters responsible for risk attitude, and builds a willingness to learn from mistakes and knowledge sharing [18].

A qualitative study which involved 67 senior managers and directors, of leading companies in Indonesia reveals that learning culture has direct impact on learning agility, but an indirect effect on work engagement [43]. Reffering to the study, this article suppose to examine the impact of learning culture on learning agility.

\section{H7: Learning Culture impacts on Learning Agility significantly}

Previous study which involved school managers and teaching staffs from 17 educational organizations found asignificant mediation effect of leadership in between learning culture and the knowledge application. Learning culture impact on leadership and then on knowledge application [44] Based on the study, this article suppose to test the impact of learning culture on leadership agility statistically.

H8: Learning Culture impacts on Leadership Agility significantly 
Another study which involved 168 employees from a major European port found that organizational learning culture impact directly on agility [45]. Based on the empirical study, this article is going to examine the impact of learning culture on strategic agility.

H9: Learning Culture impacts on Strategic Agility significantly

\section{Research Method}

This study is a quantitative reserach by using online questionnaire for gathering the data. This study used convenience and snowballing approach as sampling methods. The questionaire was distributed to the participants of halfday seminars. The seminar was a half-day knowledge sharing session for developing work engagement and learning agility in oil palm company. The seminars were conducted in Jakarta, Pekanbaru (Sumatera), and Pontianak (Kalimantan). From the three seminars, the study got 290 responese from 102 companies. Beside answering the questionaire, the seminar participants were ask to distribute it to their friends who working for other oil palm companies. From the snowballing approach, this study got 200 responses from 72 oil palm companies. Total responses were 490 but the completed and valid were only 477 responses from 132 palm oil companies.

The respondents are mostly male (85\%), has bachelor's degree (71\%), and millennials who less than 41 years old $(79 \%)$, They have been working for oil palm companies less than 11 years $(68 \%)$. They came from non-agriculture family $(80 \%)$. They are supervisors and junior managers $(84 \%)$ in the oil palm plantation in Sumatera (57\%). This study has five variables: holistic work engagement, learning agility, leadership agility, strategic agility and learning culture. All variables were measured by instrument which adapted from previous study. Based on the developed hypothesizes, the research model is display in Fig. 1.

Table 1 The Profile of Respondents

\begin{tabular}{lccc}
\hline \multicolumn{4}{c}{ Gender } \\
\hline \hline Male & 405 & $85 \%$ & $85 \%$ \\
Female & 72 & $15 \%$ & $100 \%$ \\
\hline \hline \multicolumn{4}{c}{ Born Year } \\
\hline \hline 1960 s/d 1969 & 11 & $2 \%$ & $2 \%$ \\
1970 s/d 1979 & 87 & $18 \%$ & $21 \%$
\end{tabular}

\begin{tabular}{lccc}
\hline \multicolumn{4}{c}{ Educational Background } \\
\hline \hline High School & 22 & $5 \%$ & $5 \%$ \\
Diploma & 107 & $22 \%$ & $27 \%$ \\
Bachelor & 339 & $71 \%$ & $98 \%$ \\
Master & 9 & $2 \%$ & $100 \%$ \\
\hline \hline \multicolumn{4}{c}{ Family Background Origin } \\
\hline \hline
\end{tabular}




\begin{tabular}{lccc}
1980 s/d 1989 & 182 & $38 \%$ & $59 \%$ \\
1990 s/d 1999 & 197 & $41 \%$ & $100 \%$ \\
\hline \hline \multicolumn{4}{c}{ Years of Service } \\
\hline \hline Less than 2 year & 127 & $27 \%$ & $27 \%$ \\
2 - 5 years & 114 & $24 \%$ & $51 \%$ \\
6 - 10 years & 82 & $17 \%$ & $68 \%$ \\
11 - 15 years & 76 & $16 \%$ & $84 \%$ \\
16 - 20 years & 51 & $11 \%$ & $94 \%$ \\
more than 20 years & 26 & $5 \%$ & $100 \%$ \\
\hline \hline
\end{tabular}

\begin{tabular}{lccc} 
Agriculture & 94 & $20 \%$ & $20 \%$ \\
Non-Agriculture & 383 & $80 \%$ & $100 \%$ \\
\hline \hline \multicolumn{4}{c}{ Structural Position } \\
\hline \hline Supervisor & 286 & $60 \%$ & $60 \%$ \\
Junior Manager & 115 & $24 \%$ & $84 \%$ \\
Manager & 76 & $16 \%$ & $100 \%$ \\
\hline \hline \multicolumn{4}{c}{ Location of Plantation } \\
\hline \hline Sumatra & 270 & $57 \%$ & $57 \%$ \\
Kalimantan & 207 & $43 \%$ & $100 \%$ \\
\hline \hline
\end{tabular}

Holistic work engagement was measured by 12 -indicators instrument [46]. Strategic agility was measured by the 9-indicators instrument [47] Leadership agility was measured by 12-indicators instrument [27]. Learning agility was measured by 12-indicators instrument [24]. Learning culture was measured by 8-indicators instrument [42] .

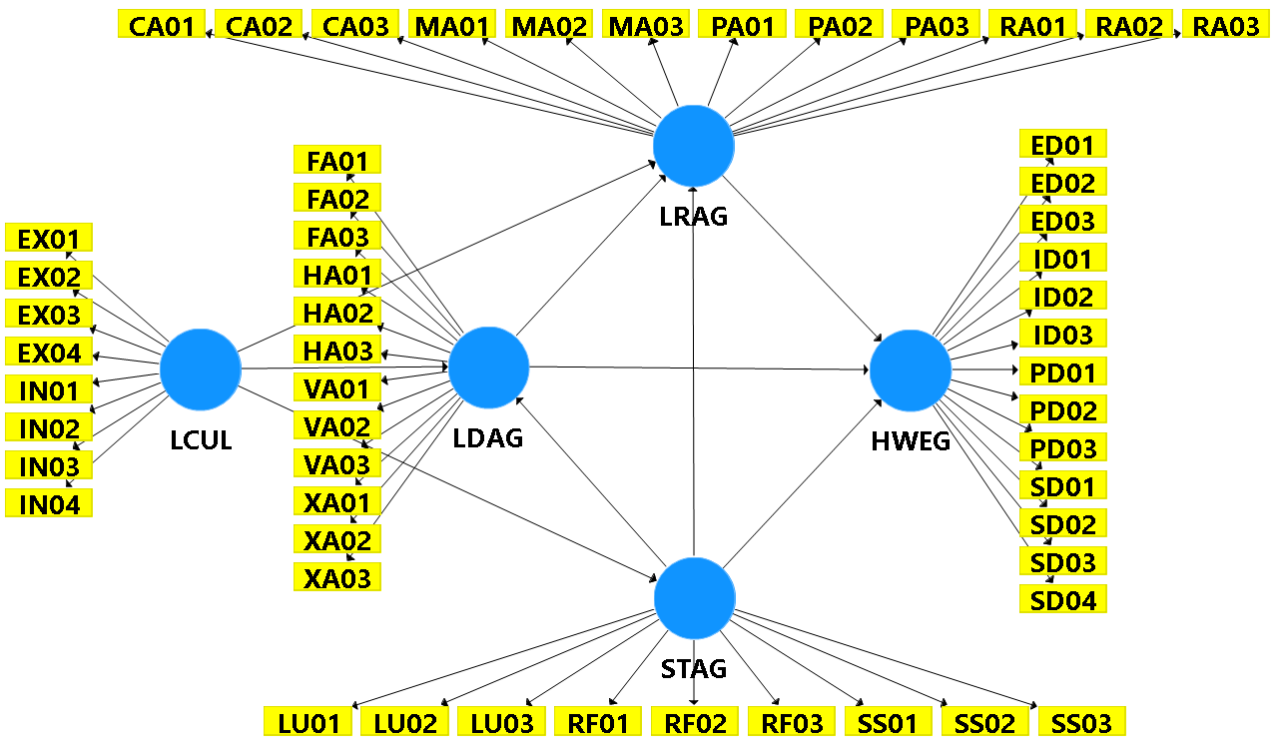

Fig. 1. Research Model

By using the gathered data, the research model was computed for validity and reliability analysis and hypothesizes testing. The gathered data was analysed by PLS-SEM (partial least square structural equation modelling) and using SmartPLS version 3.0 for data computation 
.Table 2. Validity and Reliability Analysis

\begin{tabular}{|c|c|c|c|c|c|c|c|c|c|}
\hline Item & OL & CA & $\mathbf{C R}$ & AVE & Item & $\mathbf{O L}$ & $\mathbf{C A}$ & $\mathbf{C R}$ & AVE \\
\hline \multicolumn{5}{|c|}{ HOLISTIC WORK ENGAGEMENT } & \multicolumn{5}{|c|}{ LEADERSHIP AGILITY } \\
\hline PD01 & 0,63 & \multirow{8}{*}{0,87} & \multirow{8}{*}{0,90} & \multirow{8}{*}{0,52} & VA03 & (0,61 & \multirow{12}{*}{0,94} & \multirow{12}{*}{0,95} & \multirow{12}{*}{0,61} \\
\hline ED01 & 0,68 & & & & XA01 & 0,64 & & & \\
\hline ID01 & 0,70 & & & & FA01 & 0,74 & & & \\
\hline SD03 & 0,71 & & & & FA02 & 0,76 & & & \\
\hline ID02 & 0,72 & & & & HA02 & 0,78 & & & \\
\hline PD03 & 0,73 & & & & HA01 & 0,79 & & & \\
\hline SD02 & 0,77 & & & & HA03 & 0,81 & & & \\
\hline SD01 & 0,80 & & & & FA03 & 0,82 & & & \\
\hline \multicolumn{5}{|c|}{$\begin{array}{ll}\text { LEARNING AGILITY } \\
\end{array}$} & XA02 & 0,83 & & & \\
\hline CA02 & 0,67 & \multirow{8}{*}{0,85} & \multirow{8}{*}{0,88} & \multirow{8}{*}{0,51} & VA01 & 0,84 & & & \\
\hline PA01 & 0,69 & & & & VA02 & 0,84 & & & \\
\hline $\mathrm{CA} 03$ & 0,69 & & & & XA03 & 0,85 & & & \\
\hline MA01 & 0,70 & & & & \multicolumn{5}{|c|}{ STRATEGIC AGILITY } \\
\hline RA01 & 0,70 & & & & RF01 & $\overline{0,67}$ & & & \\
\hline MA02 & 0,70 & & & & $\mathrm{SS} 02$ & 0,68 & & & \\
\hline MA03 & 0,71 & & & & SS01 & 0,71 & & & \\
\hline PA02 & 0,72 & & & & $\mathrm{SS} 03$ & 0,75 & 0,87 & 0,90 & 0,56 \\
\hline \multicolumn{5}{|c|}{ LEARNING CULTURE } & LU03 & 0,79 & & & \\
\hline EX01 & 0 & \multirow{5}{*}{0,67} & \multirow{5}{*}{0,79} & \multirow{5}{*}{0,53} & LU01 & 0,81 & & & \\
\hline EX03 & 0,65 & & & & LU02 & 0,82 & & & \\
\hline IN03 & 0,65 & & & & \multicolumn{5}{|c|}{ "Note: CA = Cronbach's Alpha } \\
\hline IN04 & 0,68 & & & & \multicolumn{5}{|c|}{$\mathrm{CR}=$ Composite Reliability } \\
\hline EX04 & 0,69 & & & & \multicolumn{5}{|c|}{$\mathrm{AVE}=$ Average Variance Extracted } \\
\hline
\end{tabular}

- Table 2 shows that several indicators (four indicators of holistic work engagement; four indicators of learning agility; three indicators of learning culture, and two indicators of strategic agility ) are excluded from the research model. Because those indicators are not valid. They have OL (outer loading) less than 0,60.All indicators in Table 2 are valid, because they have OL more than 0,60 . All variables are valid too, because they have AVE score more than 0,50 .

Table 3 support the same conclusion. All diagonally bold scores are more than 0,70 and become the biggest score in the column. It indicates that all variableas are discriminantly valid. Table 2 also show that all variables have Cronbach's Alpha (CA) and Composite Reliability (CR) score more than 0,70. Those indicate that all variables are reliable. Based on validity and reliability; all indicator are valid. All variables are valid and reliable for testing hypothesizes. 
Table 3. Discriminant Validity

\begin{tabular}{llccccc}
\hline & & {$[\mathbf{1 1}$} & {$[\mathbf{2}]$} & {$[\mathbf{3}]$} & {$[\mathbf{4}]$} & {$[\mathbf{5}]$} \\
\hline \hline$[1]$ & Holistic Work Engagement & $\mathbf{0 , 7 1 9}$ & & & & \\
{$[2]$} & Learning Culture & 0,517 & $\mathbf{0 , 7 2 9}$ & & & \\
{$[3]$} & Leadership Agility & 0,506 & 0,516 & $\mathbf{0 , 7 7 9}$ & & \\
{$[4]$} & Learning Agility & 0,564 & 0,402 & 0,343 & $\mathbf{0 , 7 1 3}$ & \\
{$[5]$} & Strategic Agility & 0,512 & 0,603 & 0,608 & 0,325 & $\mathbf{0 , 7 4 9}$ \\
\hline \hline
\end{tabular}

\section{Result and Discusion}

Table 4 shows the result of bootstrapping calculation with 500 subsamples. From nine hypothesizes, eight hypthesizes are accepted and only one hypothesis is rejected. Because H5 has t-Statistics score is less than 1,96 or p-Value more than 0,05 . It means that strategic agility does not impact on learning agility significantly.

Table 4. Hypothesizes Testing

\begin{tabular}{llcccc}
\hline & \multicolumn{1}{c}{ Hypothesis } & $\begin{array}{c}\text { Path } \\
\text { Coefficient }\end{array}$ & $\begin{array}{c}t- \\
\text { Statistics }\end{array}$ & $\begin{array}{c}p \text { - } \\
\text { Values }\end{array}$ & Result \\
\hline \hline H1 & Learning Agility $==>$ Holistic Work Engagement & 0,41 & 9,85 & 0,00 & Accepted \\
H2 & Leadership Agility $=>$ Holistic Work Engagement & 0,21 & 3,62 & 0,00 & Accepted \\
H3 & Leadership Agility ==> Learning Agility & 0,16 & 2,92 & 0,00 & Accepted \\
H4 & Strategic Agility $=>$ Holistic Work Engagement & 0,25 & 4,27 & 0,00 & Accepted \\
H5 & Strategic Agility $=>$ Learning Agility & 0,05 & $\mathbf{0 , 8 9}$ & $\mathbf{0 , 3 7}$ & Rejected \\
H6 & Strategic Agility $=>$ Leadership Agility & 0,47 & 10,11 & 0,00 & Accepted \\
H7 & Learning Culture $=>$ Learning Agility & 0,29 & 4,32 & 0,00 & Accepted \\
H8 & Learning Culture $=>$ Leadership Agility & 0,24 & 5,15 & 0,00 & Accepted \\
H9 & Learning Culture $=>$ Strategic Agility & 0,61 & 19,37 & 0,00 & Accepted \\
\hline \hline
\end{tabular}

From Table 4, this article has proved that holistic work engagement is influenced by multi-layer agility significantly. Learning agility, leadership agility, and strategic agility impact on holistic work engagement significantly. Fig 2 explains that multi-layer agility influences $46,6 \%$ on holistic work engagement. There are other influential factors $(53,5 \%)$ are not investigated in this study. Learning culture impacts on learning agility, leadership agility, and strategic agility significantly. Learning culture impacts on multi-layer agility significantly. Learning culutre impact holistic work engagement indirectly. By impacts on multi-layer agility then multi-layer agility impacts holistic work engagement. Strategic agility also does not impact on learning agility directly. Strategic agility influences leadership agility then leadership agility impacts on learning agility. 


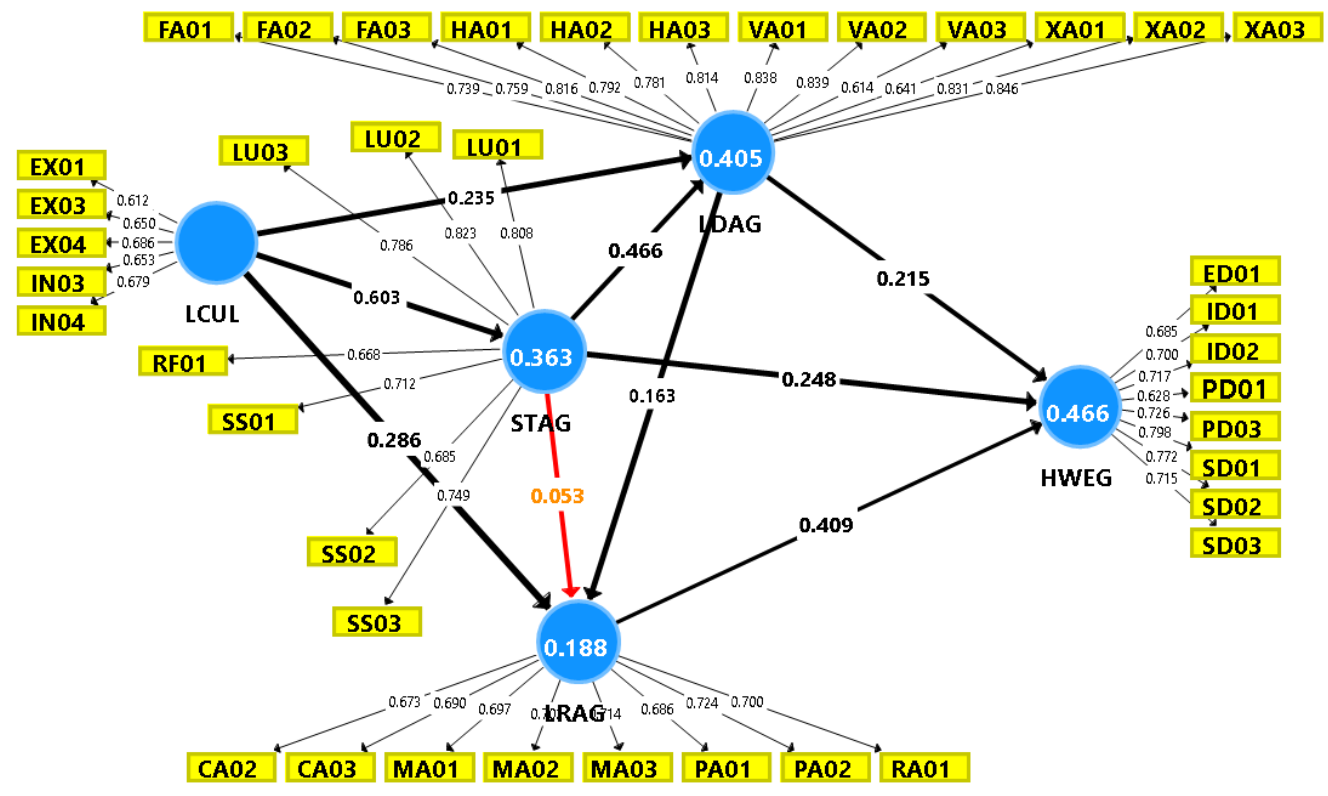

Fig.3 Empirically Tested Research Model

For reaching sustainable growth, oil palm company in Indonesia should engage their managerial resources holistically. Supervisors, junior managers, and managers should be engaged physically, intellectually, emotionally, and spiritually with their work in oil palm industry. The work engagement can be leveraged by developing multi-layer agility. Multi layer agility is a business agility in every layer of the organization.

Supervisors, junior managers, and managers should be developed the personal capability in learning agililty. Learning agility is pesonal capability in dealing with newly and complex situations. The superiors of supervisors, junior managers and managers should be developed too their personal capability in leadership agility. Leadership agility is capability to lead the group of people with speed and flexibility in dealing with continuous business changes. The top management team in oil palm company should be developed their personal capability to conduct strategy agility in organization scope.

Learning culture should be develop for sustaining the multi-layer agility. By developing and strengthening the corporate culture which facilitate individual and collaborative learning for all people in organization; business agility in individual, group, and organization layer will be stronger and then leverage work engagement of managerial resources (supervisors, junior managers, and managers) in oil palm company. 


\section{Conclusion}

For sustaining the business growth in changing environment, it need work engagement of the managerial resource holistically. Holistic work engagement can be aimed by developing multi-layer business agility. Developing learning culture is an imperative for sustaining multi-layer agility.

\section{References}

[1] J. H. Purba, Industri Sawit Indonesia dalam Perspektif Minyak Nabati Global, Bogor: Kesatuan Press, 2019.

[2] S. A. B. Choiruzzad, „Save palm oil, save the nation: Palm oil companies and the shaping of Indonesia's national interest,“ Asian Politics and Policy, zv. 11, \%1. vyd.1, pp. 8-26, 2019.

[3] A. C. Sequino a J. M. Avenido, „The world's leader in the pailm oil industry: Indonesia," Recoletos Multidisciplinary Research Journal, zv. 3, \%1. vyd.1, 2015.

[4] Kemen PPPA, Sta tik Gender Tematik: Profil Generasi Milenial Indonesia, Jakarta, 2018.

[5] J. H. Lee a C. Ok, „Drivers of work engagement: An examination of core self-evaluation and psychological climate among hotel employess,“ International JOurnal of Hospitality Management, zv. 44, pp. 84-98, 2015.

[6] A. Tymon a M. Mackay, „Developing business buccanneers: Employee expectation of emergent leaders," Human Resource Development International, pp. 1-18, 2016.

[7] D. Nold a L. Michael, ,The performance triangle: A model for corporate agility," Leadership and Organization Development Journal, zv. 37, \%1. vyd.3, pp. 341 - 356, 2016.

[8] D. Rigby a B. Bilodeau, „Management Tools and Trends 2015,“ Bain \& Company Inc., Boston, 2015.

[9] W. A. Kahn, „Psychological conditions of personal engagement and disengagement at work," Academy of Management Journal, zv. 33, \%1. vyd.4, pp. 692-724, 1990. 
[10] M. C. Buckingham a C. C. Coffman, First! Break all the rules: What the worlds greatest managers do diffierently, New York: Simon and Schuster, 1999.

[11] E. Demerouti, A. B. Bakker, F. Nachreiner a W. B. Schaufeli, Journal of Applied Psychology, zv. 86, \%1. vyd.3, p. 499, 2001.

[12] M. S. Christian, A. S. Garza a J. E. Slaughter, „Work engagement: A quantitative review and test of its relations with task and contextual performance,“"Personal Psychology, zv. 64, \%1. vyd.1, pp. 89-136, 2011.

[13] C. Maslach, W. B. Schaufeli a M. P. Leiter, „Job burnout,“Annual Review of Psychology, zv. 52, \%1. vyd.1, pp. 397-422, 2001.

[14] W. B. Schaufeli, M. Salanova, V. Gonzalez-Roma a A. B. Bakker, „The measurement of engagement and burnout: A two sample confirmatory factor analytic approach,“ Journal of Happiness Studies, zv. 3, \%1. vyd.1, pp. 71-92, 2002.

[15] J. McCann a J. W. Selsky, Mastering turbulence: The essential capabilities of agile and resilient individuals. teams, and organizations, John Wiley \& Sones, 2012.

[16] A. Ahmed, M. A. Arshad, A. Mahmood a S. Akhtar, „Holistic human resource development: Balancing the equation through the inclusion of spiritual quotient,“ Journal of Human Values, zv. 22, \%1. vyd.3, pp. 165179, 2016.

[17] C. Knight, M. Patterson a J. Dawson, „Building work engagement: A systematic review and meta-analysis investigating the effeciveness of work engagement interventions, “Journal of Organizational Behavior, zv. 38, \%1. vyd.6, pp. 792-812, 2017.

[18] N. Saputra a I. Nasip, „Learning culture as the enabler of business transformation, “ rev. Organizational Culture, IntechOpen, 2020.

[19] S. Denning, „The quest for genuine business agility,“ Strategy and Leadership, 2019.

[20] N. Borkowski a K. A. Meese, Organizational behavior in health care, Jones \& Bartlett Publishers, 2020.

[21] D. S. DeRue, S. J. Ashford a C. G. Myers, „Learning agility: In search of conceptual clarity and theoritical grounding," Indstrual and Organizational Psychology, zv. 5, \%1. vyd.3, pp. 258-279, 2012.

[22] C. L. Bedford, „The role of learning agility in workfplace performance and career advancement,“ 2011. 
[23] J. Allen, „Conceptualizing learning agility and investigating its nomological network, “2016.

[24] L. S. Gravett a S. A. Caldwell, Learning agility: The impact on recruitment and retention, Springer, 2016.

[25] N. Saputra, „Does learning culture impact directly or indirectly on work engagement in the Indonesia oil palm industry?," International Journal of Engineering and Technology, zv. 7, \%1. vyd.3.30, pp. 561-566, 2018.

[26] N. Horney, B. Pasmore a T. O'Shea, „Leadership agility: A business imperative for a VUCA world,“ Human Resource Planning, zv. 33, \%1. vyd.4, p. 34, 2010.

[27] B. Joiner, „Leadership agility for organizational quilty,“ Journal of Creating Value, zv. 5, \%1. vyd.2, pp. 139-149, 2019.

[28] J. McKenzie a P. Aitken, „Leanring to lead the knowledgeable organization: Developing leadership agility, “Strateguc HR Review, 2012.

[29] B. Joiner a S. Josephs, „Developing agile leaders,“ Industrial and Commercial Training, 2007.

[30] H. Sarwar, M. Ishaq, A. Amin a R. Ahmed, „Service leadership, work engagement and service performance: The moderating role of leader skills," Group and Organization Management, zv. 1, pp. 43-74, 2020.

[31] Y. Zheng, L. Graham, O. Epitropaki a E. Snape, ,Service leadership, work engagement, and service performance: The moderating role of a leader skill,“ Group and Organization Management, pp. 43-74, 2020.

[32] Q. Uyun, „Leadersgip agility, The influence on the organizational learning and organizational innovation and how ti reduce imitation orientation,“" International Journal for Quality Research, zv. 13, \%1. vyd.2, 2019.

[33] G. Dai, K. P. De Meuse a K. Y. Tang, ,The roe of learning agility in executive career success: The result of two field studies, “ Journal of Managerial Issues, pp. 108-131, 2013.

[34] N. N. Brueller, A. Carmeli a I. Drori, „How do different types of mergers and acquisitions facilitate strategic agility?,“ Califonia Management Review, zv. 56, \%1. vyd.3, pp. 39-57, 2014.

[35] P. Junni, R. M. Sarala, S. Y. Tarba a Y. Weber, „The role of strategic agility in acquisitions, “ British Journal of Management, zv. 26, \%1. vyd.4, pp. 596-616, 2015.

[36] S. P. Fourne, J. J. Jansen a T. J. Mom, „Strategic agilityin MNEs: Managing tensions to capture opportunities across emerging and 
established markets, “ California Management Review, zv. 56, \%1. vyd.3, pp. 13-38, 2014.

[37] A. Arbussa, A. Bikfalvi a P. Marques, ,Strategic agility - driven business model renewal: The case of an SME,“Management Decision, 2017.

[38] W. A. Nafei, „Organizational agility: The key to improve organizational performance," International Business Research, zv. 9, \%1. vyd.3, pp. 97111, 2016.

[39] R. Martin-Rojas, V. J. Gracia-Morales a M. T. Bolivar-Ramos, „Influence of technological support skills, and competencies and learning on corporate entrepreneurship in European technology firms, " Technovation, zv. 33, \%1. vyd.12, pp. 417-430, 2013.

[40] M. Khoshlahn a F. S. Ardabili, ,The role of organizational agility and transformational leadership in service recovery prediction," ProcediaSocial and Behavioral Sciences, pp. 142-149, 232016.

[41] H. van Breda-Verduijn and M. Heijboer, "Learning culture, continuous learning, organizational learning anthropologits," Industrial and Comercial Training, 2016.

[42] T. M. Rebelo a A. D. Gomes, „Conditioning factors for an organizational learning culture," Journal of Workplace Learning, 2011.

[43] N. Saputra, S. B. Abdinagoro a E. A. Kuncoro, „The mediating role of learning agility on the relationship between work engagement and learning culture,“ Pertanika Jurnal of Social Sciences \& Humanities, 2018.

[44] B. Hutahayan, „Learning culture and knowledge application: The mediating effect of transformational leadership," International Journal of Cyber Rersearch and Education, zv. 2, \%1. vyd.2, pp. 24-37, 2020.

[45] A. Pantauvakis a N. Bouranta, ,Agility, organizational learning and relationship quality in the port sector," Total Quality Management and BUsiness Excellence, zv. 28, \%1. vyd.3-4, pp. 366-378, 2017.

[46] N. Saputra, Sasmoko a S. B. Abdinagoro, „The holistic work engagement: A study in Indonesia oil palm industry,“ International Journal of Engineering \& Technology, zv. 4.9, pp. 1-7, 2018.

[47] Y. L. Doz a M. Kosonen, „Embedding strategic agility: A leadeship agenda for accelerating business model renewal,“ Long Range Planning, pp. $370-382,2010$. 